\title{
Articles
}

The Person and the Challenges

Volume 11 (2021) Number 2, p. 7-25

DOI: http://dx.doi.org/10.15633/pch.4067

Jerzy Krzanowski

Tarnów, Poland

\section{The concept of the personal}

and axiological experience in the philosophy

of K. Wojtyła - John Paul II:

a starting point of philosophical anthropology

\begin{abstract}
Philosophy, which reflects different anthropological solutions and theories of humanity, considered in the perspective of Christian philosophical anthropology in Poland, is the Thomistic phenomenology of action of K. Wojtyła - John Paul II. In this philosophical concept the starting point is the personal and axiological experience. It is analysis of the acts of conscious action. Act reveals the person (the moral significance of the person). Widely understood Wojtyla's Personalism is a chance of a creative meeting for two philosophies - from Lublin and Cracow. The more the use of his thoughts, the more developed they become.
\end{abstract}

\section{Keywords}

Person, personalism, axiology, phenomenology of action, freedom, truth, moral, starting point. 


\section{Introduction}

Man is a subject of interest to many sciences, doctrines and ways of recognition of reality. In the European culture, which was founded on the connection of Greek philosophy and the biblical tradition, assimilated by dint of Christianity $^{1}$ - each person has a particular meaning and importance. If man is considered and treated as a person, i.e. a unique unit, having in itself the supremacy towards material values, economic and social structures, when his dignity is respected, if the value and material structure are subservient to the good of the human person for its development - then we can talk about Personalism. "The human person shall always be treated as an entity and purpose, and not as a subject, whether the tool of action or remedy of the destination. The term 'Personalism' in a broader sense encompasses a philosophical doctrine, psychological, pedagogical or social accepting of the particular value of the person and postulating a comprehensive development of personality."

Related closely to Christian Existentialism, Christian Personalism stresses, that human existence is shaped not so much through relationships with the world of things, but rather through interpersonal relationships between humans and God as a person and particular man. ${ }^{3}$

The personalistic Christian philosophy, characterizing by such features, is interested chiefly in ethics and anthropology, and draws on different areas of philosophy (for example the field of methodology-also from different perspectives),

${ }^{1}$ M. Heller, Początki konfliktu i wspótistnienia, in: M. Heller, Z. Liana, J. Mączka, W. Skoczny, Nauki przyrodnicze a teologia: Konflikt i wspótistnienie, Tarnów 2001, p. 28; A. Vincelette, The Church Does Have a Philosophy of Her Own: Ruminations on Fides et Ratio and the First Principles of Catholic Philosophy, "Bogoslovni vestnik" 73 (2013) Nr 1, pp. 17-46; S. Gerjolj, Moralno in religijsko učenje in poučevanje pred novimi izzivi, "Bogoslovni vestnik" 66 (2006) Nr 2, pp. 189-203.

A. Sparty, Personalizm, in: Z. Pawlak (ed.), Katolicyzm A-Z, Poznań 1994, pp. 308-309.

${ }^{3}$ Cf. W. Szewczyk, Kim jest człowiek. Zarys antropologii filozoficznej, Tarnów 1994, pp. 110-118; R. Darowski, Filozofia człowieka, Kraków 1995, pp. 44-45; S. Odilon-Gbènoukpo, M. Snježana, Integral Education: TheologicalPedagogical Emphases in the Light of Church Teaching, "Bogoslovska Smotra" 91 (2021) Nr 1, pp. 51-72; E. Osewska, Personalizm jako fundament wychowania w szkole, in: Wychowanie a wyzwania ponowoczesności, ed. E. Osewska, Warszawa 2011, wyd. UKSW, pp. 81-90; J. Stala, Der Mensch als Person: Die bestimmende Grundlage für Johannes Paul II. in seinem Bild von der Familie, “The Person and the Challenges" 2 (2012) nr 2, pp. 41-59; E. Osewska, B. Simonič, A Civilization of Love according to John Paul II, "The Person and the Challenges" 9 (2019) nr 1, pp. 23-32, DOI: http://dx.doi.org/10.15633/pch.3359 
keeping in mind the biblical dignity of the human being- the image of God and a child of God.

Personalism seems to be that flat surface, on which the philosophical anthropology meets alike in the terms and recognition of Krapca as well in Tischneraas they both are considered to be a widely understood as the (polish) Personalism of the contemporary time. ${ }^{4}$

The leading representative of polish Personalism is Karol Wojtyła, ${ }^{5}$ who before 1978 when he was chosen as the Bishop of Rome, appeared as one of the main characters on the polish philosophical and theological scene. ${ }^{6}$ Back then this professor of ethics at Katolicki Uniwersytet Lubelski, at the same time a cardinal and metropolitan, created original and insightful concepts of the human being which was based on interpreting Thomism ${ }^{7}$ in the light of the phenomenological method (phenomenology of Max Scheler - is the object of his habilitation ${ }^{8}$ ).

Certainly, of great significance were the writings of St. John of the Cross (he studied them for his master's degree ${ }^{9}$ and doctorate ${ }^{10}$ ) and the interest in Kant's ethics. ${ }^{11}$ (In his philosophy some sort of coincidence is also visible, but without mutual dependence, with the anthropology of R. Ingarden ${ }^{12}$ ).

${ }^{4}$ S. Kowalczyk, Z refleksji nad człowiekiem. Człowiek - społeczność - wartość, Lublin 1995, pp. 23-43.

Cf. S. Kowalczyk, Człowiek w myśli współczesnej, Warszawa 1990, pp. 422-44; A. Półtawski, Wojtyła Karol Józef. Osoba i czyn, in: B. Skarga (ed.), Przewodnik po literaturze filozoficzne XX wieku, Vol. 3, Warszawa 1995, pp. 440-446; R. Buttiglione, Myśl Karola Wojtyły, Lublin 1996; G. Weigel, Świadek nadziei. Biografia Papieża Jana Pawła II, Kraków 2000; A. Boniecki (ed.), Kalendarium życia Karola Wojtyły, Kraków 2000; C. Bartnik, Personalizm teologiczny według Kardynała Karola Wojtyły, Zeszyty Naukowe KUL 1-3 (1979), pp. 51-60.

${ }^{6}$ Cf. Bibliography of Wojtyła's philosophy (to 16.10 .1978 r.): M. Filipiak, A. Szostek, Bibliografia prac naukowych kardynała Karola Wojtyły, “Zeszyty Naukowe KUL” 1-3 (1979), pp. 155-170.

${ }^{7}$ Cf. A. Rodziński, Tomizm a personalizm, “Zeszyty Naukowe KUL” 4 (1969), pp. 26.

${ }^{8}$ K. Wojtyła, Ocena możliwości zbudowania etyki chrześcijańskiej przy założeniach systemu Maksa Schelera, Lublin 1959 /dissertation/.

${ }^{9}$ Pojęcie środka zjednoczenia duszy z Bogiem w nauce św. Jana od Krzyża (dissertation direktor: I. Różycki).

${ }^{10}$ Doctrina de Fide apud S. Joannem de Cruce (dissertation director: R. Garrigou-Lagrange). Cf. polish translation: Zagadnienie wiary w dziełach św. Jana od Krzyża, Kraków 1990.

${ }^{11}$ J. Galarowicz, Na ścieżkach prawdy. Wprowadzenie do filozofii, Kraków 1992, pp. 524; about Scheler and Kant cf. K. Wojtyła, Wykłady lubelskie, Lublin 1986, pp. 22-56.

${ }^{12}$ T. Styczeń, Metoda antropologii filozoficznej w "Osobie i czynie", "Analecta Cracoviensia" 5-6 (1973-1974), p. 113; cf. M. Jaworski, Koncepcja antropologii filozoficznej w ujęciu 
The Pastoral Constitution of Vaticanum II Gaudium et Spes, which Wojtyła co-authored, presented human anthropology as the gift, possessing specific dignity, ${ }^{13}$ implementing the sincere gift of self. Wojtyla develops an anthropology, which is fundamental for such a consideration, and it is important for his concern in morality and in general a "person standing in deeds and by deeds". ${ }^{4}$ The threat of humanism from anti-metaphysical, idealistic, subjectivist, positivist, agnostic, structuralist, deconstructional attitudes, and also the reduction to unidimensional psychology - offer a special opportunity for the importance of developing a solid philosophy of man. This is especially so when modern science, and even the culture (in which the materialistic civilization is dominant together with the technical culture) is not giving the holistic vision of human. "The true about the human person is necessary in order to follow properly and humanely live, to responsibly perform humanly - personal and social task". ${ }^{15}$ Echoes realizing this task of philosophy can be read from the Pope's speeches of John Paul II, (as well as from the Christian philosophical morality which is the principle of the encyclical Veritatis Splendor $\left.{ }^{16}\right)$.

As the Wojciech Chudy writes in the introduction to the book of the outstanding Italian expert on Karol's Wojtyla thought - Rocco Buttiglione's: "Wojtla's Personalism is the answer, key to the arrogance of force against the truth, country authorities against the person and the arrogance of arbitrary freedom to solidarity...."

Kard. Karola Wojtyty, "Analecta Cracoviensia” 5-6 (1973-1974), p. 103-104; A. B. Stępień, Studia i szkice filozoficzne, Vol. 2, Lublin 2001, pp. 269-277.

${ }^{13}$ Cf. Gaudium et spes. Pastoral Constitution on the Church in the Modern World, nr 17; cf. John Paul II's encyclical, 1979: Redemptor Hominis, nr 12 (Wrocław 1994, p. 32-36); Jan Paweł II, Przekroczyć próg nadziei, Lublin 1994, p. 147-151; Jan Paweł II, Mężczyzną i niewiasta stworzyt ich, Watykan 1986, pp. 54-97.

${ }^{14}$ Cf. J. Galarowicz, Na ścieżkach prawdy..., p. 524.

${ }^{15}$ Z. Zdybicka, Praktyczne aspekty dociekań przedstawionych $w$ dziele "Osoba i czyn", "Analecta Cracoviensia" 5-6 (1973-1974), p. 202; W. Szewczyk, Jana Pawła II widzenie świata, "Currenda" 4 (1993), pp. 570-585; cf. A. Drożdż, Jan Paweł II nauczycielem moralności, "Currenda" 4 (1993), pp. 586-599.

${ }^{16}$ Cf. Veritatis Splendor, nr 31-53; cf. Fides et Ratio; T. Ślipko, Filozoficzne aspekty moralności aktu ludzkiego w encyklice Veritatis Splendor, in: W prawdzie ku wolności. W kręgu encykliki Veritatis Splendor, red. E. Janiak, Wrocław 1994; pp. 245-258; W. Szewczyk, Jana Pawła II..., pp. 577.

${ }^{17}$ W. Chudy, Wprowadzenie - na odsiecz prawdzie o osobie ludzkiej, in: R. Buttiglione, Myśl Karola Wojtyly, pp. 12-13; Professor Chudy returns here at the same time to note that actually 
The book of Wojtyła's Person and Act (Krakow 1969) plays the fundamental role in the real philosophical study about the human person. The presented anthropology and the book itself became the subject of a special conference, for example, (KUL 1970). ${ }^{18}$ Many philosophers analyzed (and analyze) the philosophical conception. ${ }^{19}$ The need to develop this thought is even greater, when Karol Wojtyla - the philosopher, became John Paul II and his forces were directed at the service of the whole universal pastoral Church. This opened up the vast horizons of science for those who wish to work on the urgent creation of the theory of man, which would allow the teachings of natural and humanistic development to take into account the genuine responsibility for man. ${ }^{20}$

\section{Cardinal Wojtyła's philosophical sources about anthropology}

Although in his introductory anthropology Cardinal. K. Wojtyla tries to be methodologically autonomous - i.e., independent, neutral with respect to philosophical or theological systems ${ }^{21}$ we can distinguish two main sources for his thoughts: Thomism (the philosophy of being) and Phenomenology (gleaned mainly from M. Scheler ${ }^{22}$.

Of course, the first chronological source of thought and doctrine for K. Wojtyła - John Paul II is still a Saint - John of the Cross and his mysticism. ${ }^{23}$ To be able to use his works K. Wojtyla specifically learned Spanish during the war. This issue, however, goes so beyond the nature of our work that we will

this huge achievement of philosophical and theological thought in Poland is unappreciated, and the teaching is often done with trivial enthusiasm. W. Chudy, Wprowadzenie - na odsiecz prawdzie o osobie ludzkiej, p. 18.

${ }^{18}$ Cf. Dyskusja nad dziełem Kard. Karola Wojtyły "Osoba i czyn", "Analecta Cracoviensia" 5-6 (1973-1974) pp. 49-297.

${ }^{19}$ For example: W. Stróżewski, T. Styczeń and J. Galarowicz, J. Gałkowski, S. Grygiel, M. Jaworski, J. Kalinowski, S. Kowalczyk, M. A. Krąpiec, A. Półtawski and others. Cf. W. Stróżewski, Istnienie i wartość, Kraków 1981.

${ }^{20}$ R. Buttiglione, Myśl Karola Wojtyły, p. 421.

${ }^{21}$ Cf. T. Styczeń, "Transcendencja - drugie imię osoby" czyli człowiek widziany z "niskości” doświadczenia samego siebie i z "wysokości krzyża”, "Znak” 401 (1988), p. 3.

${ }^{22}$ Cf. M. Scheler, Resentyment a moralność, Warszawa 1997.

${ }^{23}$ J. Kupczak, W stronę wolności. Szkice o antropologii Karola Wojtyły, Kraków 1999, pp. 37-47; Cf. K. Wojtyła, Zagadnienie wiary.... 
not discuss the great mystic and thinker in this paper and focus on the philosophical sources.

The thought of Karol Wojtyła is not pure Thomism, but, as mentioned above, its reinterpretation. The author of Persons and Act wants to bring this philosophical thought to modern man. "This is undoubtedly the 'Thomist Personalism, but not a literal reproduction of Thomism. Cardinal Wojtyla's Thomism is 'existential' in the sense that it is a recognition of a particular man in his activity, personal experience, and the experience of values, etc". ${ }^{24}$

The starting point of traditional Thomism and Wojtyła's philosophy is different, because whereas in Thomism the starting point is God, then in Wojtyla's interpretation the starting point is man, as a person. This is due to the recognition of human experience as a special kind of experience that is irreducible to a different kind of superhuman reality experience. "Wojtyła is interested here in a man who becomes a reality through deeds". ${ }^{25}$

Considering that the second source of his Personalism is Phenomenology, does not mean that Wojtyla fully accepted it. Wojtyła emphasized that the Christian thinker (especially the theologian) who uses phenomenology as a method cannot be a consistent phenomenologist.

This is especially about the objectivity of ethical principles. Ethical evaluation that appears "in human experience" "on the occasion of the action" is unacceptable. ${ }^{26}$ Nevertheless, the author of Person and Act freely uses phenomenological terminology. "Phenomenology fully with the instrumental function, is an effective method in explaining human nature, especially the explication of its dynamism". ${ }^{27}$ Discussing the philosophical thought of Wojtyła, in the context of contemporary philosophy, R. Buttiglione characterized it as a kind of union of Pascal and St. Thomas Aquinas. ${ }^{28}$

${ }^{24}$ S. Kowalczyk, Człowiek w myśli..., p. 423.

${ }^{25}$ J. Galarowicz, Człowiek jest osobą. Podstawy antropologii filozoficznej Karola Wojtyty, Kęty 2000 (IInd ed.), pp. 46-49.

${ }^{26}$ K. Wojtyła, Ocena możliwości zbudowania..., p. 125; cf. S. Kowalczyk, Człowiek w myśli..., pp. 423-424; R. Palacz, Klasycy filozofii, Warszawa 1987, p. 246.

${ }^{27}$ S. Kowalczyk, Tomistyczno - fenomenologiczny personalizm kard. Karola Wojtyły, "Ateneum Kapłańskie" 455-456 (1985) p. 85. Regarding the usefulness of phenomenology to explain the human being cf. W. Szewczyk, Czy fenomenologia może się przydać psychologii współczesnej, "Znak” 271 (1977), pp. 35-45.

${ }^{28}$ R. Buttiglione, Myśl Karola Wojtyty, p. 389-390. It’s Pascal's idea, that «you have to love the good, to be able to know the truth»: "in the world, there is enough darkness so the one 
The author of Person and Act ${ }^{29}$ did not attempt to create some metaphysics for both strands of philosophy. ${ }^{30} \mathrm{He}$ was ethic and his interest in a man, caring for a human being was ethically and anthropologically oriented. In ethics and anthropology connected with it, he saw the possibility of combining Thomistic Personalism with a phenomenological method, creating, as Stępień calls it: the so-called Thomistic Phenomenology. ${ }^{31}$ Karol Cardinal Wojtyla - John Paul II developed that "original character of realistic phenomenology and realistic ontology of Personalism". ${ }^{32} \mathrm{He}$ is the original creator of the theory of man, realistic (as the concept of M. A. Krąpiec OP), but separate from the shots so strictly Thomistic (see: Krąpiec) and phenomenological (which in a sense it is the concept of Tischner). It is a philosophy of the human person, which is objectively interested in the really existing man - it was given in the experiment (realistic philosophy, Thomism), and it is also anthropology, in which the fundamental role is played by the human inner experience (Phenomenology). This anthropology is a synthesis of the description of the existence and nature of man, in which metaphysics is the basis of ethics, and the axiological order flows from the ontological order. ${ }^{33}$

\section{The axiological-personal inner experience}

Characteristic of Wojtyła's theory of man is the 'unique nature of its building". ${ }^{34}$ The first is experience, insight. Thus, the starting point counted only is direct, personal contact with cognition itself, which is here the source and cognitive validation.

who does not love the truth, also could not find it”. R. Buttiglione, Myśl Karola Wojtyty, p. 390.

${ }^{29}$ Another version of the translation is: The Acting Person. Cf. Ibid., Boston 1979.

${ }^{30}$ K. Wojtyła, Słowo końcowe, "Analecta Cracoviensia" 5-6 (1973-1974), p. 249.

31 A. B. Stępień, Fenomenologia tomizująca w książce "Osoba i czyn”, "Analecta Cracoviensia” 5-6 (1973-1974), pp. 155-157.

32 J. Galarowicz, Człowiek jest osobą. Podstawy antropologii filozoficznej Karola Wojtyły, Kraków 1994, p. 254.

${ }^{33}$ J. Galarowicz, Człowiek jest osoba...., (IInd ed.), pp. 46-55, 59-64.

${ }^{34}$ T. Styczeń, "Transcendencja - drugie imię..., p. 3. 
The starting point of Wojtyła's philosophical anthropology is human experience $-^{35}$ specific experience of man. ${ }^{36} \mathrm{~A}$ general theory of being (metaphysics) already has its basis in experience, but anthropology - by the Krakow- Lublin philosopher and theologian - has its own source "in a just the right experience". ${ }^{37}$ It is an experience conceived in a way that is both phenomenological and experiential as subject-object and subjective - objective. It is not a concept of phenomenological experience, occurring in the empiricist way of thinking, because phenomenological experience excludes organic unity of knowledge, as well as many unique experiences of the unity of the individual and reducing the experience only to sensual cognition. Wojtyła's concept is realistic experience that is 'sober empiricism. ${ }^{38}$

Cardinal Wojtyła uses a whole philosophical legacy, both AristotelianThomist current philosophy of being and the Platonic-Augustinian (as the mainstream of modern philosophy of consciousness), which uses the interpretation of Thomas's experience. He believed that these trends mutually enrich and complement each other. Wojtyła to some extent combines and synthesizes (in this regard), the two main currents of philosophical reflection. ${ }^{39}$ Although one does not intend to create any metaphilosophy, however, his focus on man "has to some extent become an attempt to merge two somewhat philosophical orientation of two philosophies". ${ }^{40}$ (It is not a 'maximalist merge').

There's no falling in eclecticism - it merely arises from a methodological pedantry: openness to everything in the philosophy stand 'the test of experience', i.e. 'attempt to access.' ${ }^{41}$ This stems from his desire to take experience in all its fullness, not blurring some of its dimensions, out of concern for the truth

${ }^{35}$ About the phenomenon of the human person as the starting point of the whole system of Personalism of K. Wojtyła cf. C. Bartnik, Personalizm teologiczny..., pp. 51-53.

${ }^{36}$ Cf. W. Dłubacz, Filozoficzne podstawy nadziei, w: T. Styczeń, Z. Zdybicka (ed.), Czytajac "Przekroczyć próg nadziei", Lublin 1995, p. 254.

${ }^{37}$ K. Wojtyła, Słowo końcowe, p. 247; cf. Objections to this topic: S. Kamiński, Jak filozofować o człowieku, "Analecta Cracoviensia" 5-6 (1973-1974), pp. 73-79; J. Kalinowski, Metafizyka i fenomenologia osoby ludzkiej. Pytania wywołane przez "osobę i czyn", "Analecta Cracoviensia" 5-6 (1973-1974), pp. 63-71; M. Gogacz, Hermeneutyka osoby i czynu (rec. ksiażki księdza kard. K. Wojtyly Osoba i czyn. Kraków 1969), "Analecta Cracoviensia" 5-6 (1973-1974), pp. 125-138.

${ }^{38}$ K. Wojtyła, Problem doświadczenia w etyce, "Roczniki Filozoficzne" 2 (1969), p. 6.

${ }^{39}$ J. Galarowicz, Człowiek jest osobą..., p. 87.

${ }^{40}$ K. Wojtyła, Osoba i czyn, Kraków 1969, p. 23.

${ }^{41}$ T. Styczeń, "Transcendencja - drugie imię..., p. 4. 
of science. "In this creative restlessness beats and pulsates what is most deeply human - the search for truth, the insatiable need for good, hunger for freedom, nostalgia for the beautiful, and the voice of conscience". ${ }^{42}$

This perception of the unity of experience which includes both a sensual and mental element implies that the description of the experience is connecting closely (but not identical ${ }^{43}$ ) with the explanation of experience, in his understanding. It is the foundation and the 'life-giving source' to obtain contact with reality - says Wojtyła. ${ }^{44}$ In other words, phenomenology is combined with ontology. ${ }^{45}$

In the human perception inner experience plays a major role, it being noted that $\mathrm{K}$. Wojtyła seeks to join the internal and external way of looking at the human, starting from the duality of human experience, the inevitable - by Wojtyła the knowledge of man, in direct contact with the cognitive human. There are two sources of the disproportionate philosophical conception of man - the basis of methodological analysis and clarification. ${ }^{46}$

The experience of moral obligation is geared to the truth and discovers a man, as a person, its objective nature, protecting it in front of subjective creationism. On the one hand, a person does not create truth, but discovers the truth, on the other hand, no one can force a person to realize this truth. The concept of selfdetermination and man's obligation to the truth and to his own personal being are also revealed here. ${ }^{47}$

The interest in moral problems naturally comes from the phenomenon of inner experience, to capture the moral activity of the human person, its characteristics, personal wealth, and the complexity of the reality of human existence.

The starting point of the anthropology of $\mathrm{K}$. Wojtyła's inner experience, are the "acts of consciousness analysis of moral action". ${ }^{48}$ In other words, the experience of morality is closely related to the human experience, it is well-established.

${ }^{42}$ Redemptor Hominis, nr. 18.

43 Cf. objection: K. Kłósak, Teoria doświadczenia człowieka w ujęciu Kardynała Karola Wojtyły, “Analecta Cracoviensia” 5-6 (1973-1974), pp. 81-84.

${ }^{44}$ K. Wojtyła, Słowo końcowe, p. 247.

${ }^{45}$ J. Galarowicz, Na ścieżkach prawdy..., p. 525.

${ }^{46}$ K. Wojtyła, Słowo końcowe, p. 250; cf. J. Galarowicz, Człowiek jest osobq..., pp. 92-93.

${ }^{47}$ W. Chudy, Wprowadzenie - na odsiecz..., p. 13.

${ }^{48}$ S. Kowalczyk, Człowiek w myśli..., p. 425. 
The unity of these two experiments does not interfere with the building of two related though different sciences: anthropology, philosophy and ethics (ethics - the so-called. Shutdown of the parentheses) ${ }^{49}$ It reveals the fact that it is impossible to build a philosophy of values and goods in isolation from the ontology and anthropology (and vice versa), since these considerations need to be combined..$^{50}$ This is a thinking -related (as in Tischner) to axiology. But whereas Tischner in his 'thinking by the values' stops at the axiological aspect which (for Levinas) is the primary emphasis - then "...Wojtyła believes that the understanding of man as a value and a gift for another person assumes a specific structure of the ontological person".51

\section{The phenomenology of action}

The main experience, for Cardinal Wojtyła, is the experience of the act, "the study of an action that reveals a person: a study of person by action".52 The starting point of both anthropology and ethics, a special place of mutual implication, is the conditioning of the human experience and the experience of morality. In the experiment is the act - which at the same time is given from the experiential and presents itself ${ }^{\mathfrak{f}_{3}}$ as an objective reality - the man involved, the human being, ${ }^{54}$ revealing himself as "aware of itself as the cause of action", the specific 'I' - a person..$^{55}$

${ }^{49}$ J. Galarowicz, Człowiek jest osobq..., pp. 96-97.

The two pillars of this philosophy are concept and consciousness, the philosophy of freedom, the theory of morality and the philosophy of inter-subjectivity. J. Galarowicz, Jabliźni - wspólnota (Karola Wojtyły teoria uczestnictwa), "Studia Filozoficzne" 2-3 (1990) p. 159.

${ }^{50}$ K. Wojtyła, “Znak, któremu sprzeciwiać się będą”, Poznań-Warszawa 1976, p. 23.

${ }^{51}$ J. Galarowicz, Człowiek jest osobą..., p. 97.

${ }^{52}$ K. Wojtyła, Osoba i czyn, p. 14; cf. R. Buttiglione, Etyka w kryzysie, Lublin 1994, p. 209; R. Buttiglione, Myśl Karola Wojtyły, pp. 175-253.

${ }^{53}$ Regarding the human's consciousness and its function of discovering (which doesn't mean the acceptance to subjectivity and idealism) would place - in some sense - the phenomenological Thomism of Wojtyła already in the post-Cartesian philosophy. A. Półtawski, Człowiek jako istota realizująca się w czynie. Antropologia Karola Wojtyły a Henri Eya analiza świadomości, "Studia Philosopiae Christianae" 2 (1981), pp. 135-148.

${ }^{54}$ J. Galarowicz, Człowiek jest osobą..., pp. 97-101.

${ }^{55}$ K. Wojtyła, Osoba i czyn, p. 82. 
The extraction of the original content of the experiment done by the phenomenological method - gradually, by induction (a further reduction). This phenomenology seeks to ontologically describe the actually existing human being. ${ }^{56}$ the statements expressing "the only reasons that make facts contradictory", that is, the descriptive statements "starting from the starting point, the dynamisms" showing who the person is.

The point of arrival of anthropology in Wojtyła's metaphysics of the human person, ${ }^{57}$ is expressing assertion "the only reasons that make facts contradictory", that is, the statements expressing "the only reasons that make facts contradictory" show who a man, a human being is. It is about the "dynamisms that are stated at the starting point" ${ }^{58}$, that are included in descriptive sentences. "Wojtyła's phenomenology of the human person is an ontology in the sense that is based on the experience of man, shows who the human person is and what is its structure".59

A personalistic concept of experience underlies this anthropology. Wojtyła's concept differs from the Aristotelian-Thomistic shots and moves closer to the phenomenological interpretation. 'The experience' is also a cognitive contact with the sphere of values. Moral experience is specifically interested in ethics. His approach to 'experience' is characterized by a 'sober empiricism', which does not limit it to the area of sensory perception, nor does it depreciate in favor of intellectual knowledge. ${ }^{60}$

M. Jaworski also notes that the concept of experience at the same time tries to overcome the thomistic psychologism and idealism of Husserl, leading the explanation for the data to realism. "Distributed because it contains a moment, the reality of a particular entity". ${ }^{61}$ Human experience including "...the experience of morality in its dynamic aspect that is existential, is the author's broad ground of understanding people, the inspection of the action" ${ }^{32}$

The approach of the Lublin's and Krakow's thinker is a personalistic dimension of experience. Experience is an act of experience of the human person. As its starting point it refers to the subjective experience of man. It accepts

\footnotetext{
${ }^{56}$ J. Galarowicz, Na ścieżkach prawdy..., p. 526.

${ }^{57}$ S. Kowalczyk, Człowiek w myśli..., p. 425.

${ }^{58}$ T. Styczeń, Metoda antropologii..., p. 112.

59 J. Galarowicz, Na ścieżkach prawdy..., p. 526.

${ }^{60}$ S. Kowalczyk, Tomistyczno-fenomenologiczna..., p. 87.

${ }^{61}$ M. Jaworski, Koncepcja antropologii..., p. 106.

${ }^{62}$ K. Kłósak, Teoria doświadczenia..., p. 81.
} 
subjectivity, but rejects subjectivism. Man is the "subject and experiencing yourself as a person". ${ }^{63}$ Consciousness is the human element and not the whole.

To human self-consciousness, consciousness belongs and the whole realm of the unconscious, subconscious or pre-consciousness. ${ }^{64}$ Self-knowledge can cognitively grasp the self-acting subject as a subject.

It is the treatment of the human person both in its objectivity and subjectivity. The analysis of the human consciousness shows the specific empowerment of the subject of experience - self-experience and self-understanding by reference to the subjective human experience. This analysis also reveals that the subject realizes the potentiality also to consciousness and independently of it, and that efficacy is related to human activity. When the

happening is a work of nature, this action is the work of a person. The potentiality of this action shows the unity and identity of the human ego. ${ }^{65}$ "A man going through his deed as an action that is causally related to his own 'I"'. ${ }^{66}$

The human person is recognized by his analysis of human experience, the experience expressed by I do - determined by self-determination; I do, the 'human factors', the 'act of human', the disclosing person. ${ }^{67}$

The human act is contrasted with happening and experiencing.

It reveals to us the ethical Personalism of Wojtyła. This Personalism is the typical synthesis of the metaphysical and liberal kinds of Personalism. The key to this Thomistic and phenomenological philosophy is the moral significance of the person. ${ }^{68}$

${ }^{63}$ K. Wojtyła, Osoba i czyn, p. 56.

${ }^{64}$ R. Forycki, Antropologia w ujęciu Kardynała Karola Wojtyły, "Analecta Cracoviensia" 5-6 (1973-1974), p. 120.

${ }^{65}$ R. Forycki, Antropologia w ujęciu Kardynała Karola Wojtyły, "Analecta Cracoviensia" 5-6 (1973-1974), p. 119.

${ }^{66}$ M. A. Krąpiec, Człowiek - suwerenny byt osobowy w ujęciu K. Wojtyły, "Zeszyty Naukowe KUL" 1-3 (1979), p. 67.

${ }^{67}$ J. Galarowicz, Na ścieżkach prawdy..., pp. 526-527.

${ }^{68}$ W. Chudy, Pedagogia godności. Elementy etyki pedagogicznej, Lublin 2009, p. 34-36; Cf. O. Höffe (ed.), Lexikon der Ethik, München 1977, p. 182. 


\section{Experience the freedom of transcendence}

A necessary condition in human action, a constitutive element of man, revealing the essence of his personal subjectivity - as discussed by Wojtyła - is the bond of human freedom from the inner self? addressing those truths that I am exploring. This experimental data centers experience itself as the irreducible identity is the cognitive act of the human and touting the throes of the 'normative power of the truth'. It reveals to us here the human ego, which is subject and object at the same time: "As someone who is himself in a certain way subjectively given as a subject of cognition and at the same time as objectively assigned to himself as the subject of freedom" ${ }^{69}$ Man experiences himself here, as requested by the truth of freedom, and thus also responsible for himself - responsible for his fulfillment (or non-compliance), for being, to remain together - me as me. ${ }^{70}$

This self-determination is the core of human freedom, the freedom that implies making something, human efficacy and consequently - the act of the disclosing person. ${ }^{71}$

Human consciousness is not confined to immanence. A person in his subjectivity must reflexively relate to his judgments, thoughts, recognizing their truth or falsity, accepting or rejecting them. And here comes the element of axiology, any (existing in a world of subjectivity) criterion of objectivity, conditioning the functioning of a person as a person. Subjectivity, which is also a correlate of the transcendent me in the objective world, including openness to dialogue with another person (the alter-persona). ${ }^{72}$ And here appears the concept, the definition of a person as a specific correlate of truth (affirmation and self-dependence).

${ }^{69}$ T. Styczeń, "Transcendencja - drugie imię..., p. 7.

${ }^{70}$ K. Wojtyła, Osoba - podmiot i wspólnota, "Roczniki Filozoficzne” 2 (1976), pp. 7-17; cf. J. Merecki, T. Styczeń, Veritatis Splendor - encyklika o wolności, in: W prawdzie ku wolności..., pp. 208-211.

J. W. Gałkowski, Samostanowienie osoby w ujęciu kardynała Karola Wojtyły, "Zeszyty Naukowe KUL" 1-3 (1979), p. 78.

${ }^{72}$ Cf. W. Chudy, Rozwój filozofowania a "pułapka refleksji". Filozofia refleksji i próby jej przezwyciężenia, Lublin 1995, p. 91-92; Jan Paweł II, Mężczyzna i niewiasta..., pp. 33-40.

When according to Husserl's theory the fundamental reality is the transcendental $I$, according to Wojtyła the fundamental reality is personal subjects, personal entities (the relation $I-Y O U$ is important however secondary). Meanwhile in Thomism the basics of social participation is laid in the social dimension of a human being, so according Wojtyła they are in the personal subject because "the ability to participate is possible on a specific personal level of existence”. J. Galarowicz, Ja - bliźni..., pp. 162-165,167-168. 
The experience of truth defines a person and with his 'axiological moment' is obligatory to act in accordance with the truth. ${ }^{73}$

"The problem of freedom and truth is an important aspect of the teaching of Pope John Paul II..."74 arising directly out of concern for (every) man, for every human being. And threatening man "totalitarianism is born out of a denial of objective truth", 75 which glows and "shines in all the works of the Creator, in a special way in man, created in the image and likeness of God (cf. Gn. 1.26): the truth enlightens the mind and shapes human freedom, which in this way is carried out in the knowledge and love of the Lord". ${ }^{6}$ Man's questions "about the meaning and limits of freedom, of social order and inalienable rights" simply reveals the legacy of truth, which is the Christian heritage that leads to God the source of truth. ${ }^{77}$

\section{Conclusion}

To conclude this article we would like to mention that the Thomist M.A. Krąiec OP commenting on Person and Act talked about the affirmation of the person body human act - by this act. However, it is believed, that Karol Wojtyła did not used Thomas's achievements to the end, ${ }^{78}$ and that actually, this is not a philosophy of man in the strict sense, but a 'study of the philosophy of man' - and more specifically with ethical anthropology. ${ }^{79}$ And the anti-Thomist J. Tischner criticizes even knowing a person by the act, believing that "the reality of the

${ }^{73}$ W. Chudy, Rozwój filozofowania..., p. 92.

${ }^{74}$ J. Królikowski, Jan Paweł II a powrót do chrześcijańskich korzeni Europy, "Currenda" 4 (1993), p. 612. Cf. Texts from symposium about encyclical Veritatis Splendor: W prawdzie ku wolności...; cf. Redemptor Hominis, nr. 12.

${ }^{75}$ Centesimus Annus, nr. 44.

${ }^{76}$ Veritatis Splendor, Intoduction.

${ }^{77}$ J. Życiński, Służąc człowiekowi i prawdzie. Piętnastolecie Pontyfikatu Jana Pawła II, "Currenda" 4 (1993), p. 563; I. Dec, Blask prawdy w wolności i wolność w prawdzie, in: W prawdzie ku wolności..., pp. 113-115; J. Krucina, "Prawda o człowieku” miara wolności, in: W prawdzie ku wolności..., pp. 132-143; cf. J. Guitton, Mój testament filozoficzny, Warszawa 1999.

${ }^{78}$ However particularly underlined is the ability of using the Augustinian theory which supports the Thomistic anthropology. Cf. M. A. Krąpiec, Człowiek-suwerenny byt..., pp. 65-70.

${ }^{79}$ M. A. Krąpiec, Książka Kardynała Karola Wojtyty monografia osoby jako podmiotu moralności, "Analecta Cracoviensia" 5-6 (1973-1974), pp. 57-61. 
person explodes into action, but to know people could walk quite independent paths ${ }^{\prime \prime}{ }^{80} \mathrm{He}$ also proposes abandoning Thomism to the Augustinian current, ${ }^{81}$ as well as links to the Heideggerian "becoming".

Despite these reservations, there is no doubt that K. Wojtyła - John Paul II is a representative of 'fair humanism', recognizing the existence of philosophy as a philosophy first. The main thesis of his thoughts about man is drawn from St. Thomas, always with the current thesis that man - the human person is the most worthy and most perfect creation. ${ }^{82}$ John Paul II, who "created the Christian philosophy of the human person" puts contemporary philosophy of requirements (among others in the encyclical Fides et Ratio) to recover its sapiential dimension philosophy, to show that man is able to know the objective truth (adaequatio rei et intellectus), that philosophy is truly a metaphysical dimension, i.e. trying to get to the foundation, the absolute (Absolute), final clarification. ${ }^{83}$

Karol Wojtyła - as a scholar and John Paul II - the Pope oft times shows that you cannot contest Thomism without giving something in return, his this philosophical thought ${ }^{84}$ - a philosophy that is developing in Poland mainly today (though not exclusively) by (broadly defined) in Lublin Krąpiec's school. In the encyclical Fides et Ratio in 1998 he writes explicitly of the "perennial newness of the thoughts of St. Thomas Aquinas", characterized by the 'courage of the truth' and 'intellectual honesty' and reminds us that "...the Church rightly consistently proposing St. Thomas as a master of thought and a model of the right way to do theology". and transcendent truth" $\left.{ }^{36}\right)$. However, he does not close himself in this system and,

${ }^{80}$ J. Tischner, Metodologiczna strona dzieła "Osoba i czyn", "Analecta Cracoviensia" 5-6 (1973-1974), p. 89.

${ }^{81}$ It's interesting that L. Kuc accuses Wojtyła of «not overcoming the Neo-Platonism». L. Kuc, Uczestnictwo w człowieczeństwie “innych”?, "Analecta Cracoviensia” 5-6 (1973-1974), pp. 188-189.

${ }^{82}$ J. Galarowicz, Człowiek jest osobq..., p. 54-56; W. Stróżewski, Średniowieczne teorie wartości, in: J. Legowicz (ed.), Historia filozofi średniowiecznej, Warszawa 1979, p. 422.

${ }^{83}$ J. Kupczak, W stronę wolności..., pp. 58, 125-130.

${ }^{84}$ Regarding the theory of St. Thomas cf. Jan Paweł II, Przekroczyć próg nadziei, pp. 41-43. Thomas “... is continually the master of philosophical and theological universalism". Jan Paweł II, Przekroczyć próg nadziei, p. 43; cf. Veritatis Splendor, nr. 14, 31-5; Fides et Ratio, nr. 43-44, 57-63.

${ }^{85}$ Fides et Ratio, nr. 43; cf. Fides et Ratio, nr. 44.

${ }^{86}$ J. Kupczak J., W stronę wolności..., pp. 125-130. 
as mentioned above, he is mainly looking for the truth in other philosophical thoughts, ${ }^{87}$ which, after all, contributed much to the development of culture not forgetting those (mainly Phenomenology, but also a part of Existentialism, Hermeneutics and to some extent the Philosophy of Dialogue ${ }^{88}$ ), which draws Tischner and under its influence - Polish substantial intellectual environment. This is not eclecticism (which Pope John Paul II believes as a "methodological error" or hidden historicism ${ }^{89}$ ), but he is looking for the grains of truth. This is - as mentioned above - out of concern for the truth of John Paul's teachings. ${ }^{90}$

Thus, the philosophy of K. Wojtyła is seen here as an opportunity for a more complete look at man as 'adequate anthropology' ${ }^{\text {'1 }}$ - in terms of the starting point of philosophical anthropology and the consequences resulting from it. It is seen as a chance to draw on the thoughts of even such a variety of contemporary thinkers - as Krąpiec and Tischner.

Science, the study of the world, is inextricably linked with man - the subject and object of research. Civilization, science, culture - it's just about man - Homo sapiens. So, let's look at the end of a speech by K. Wojtyła - John Paul II to the rectors of Polish universities: "Speaking of study, we think about culture in its universal dimension, as well as individual nations. Study because it is one of the essential pillars. Whenever I talk about culture what always comes to my mind are the words of St. Thomas Aquinas: Genus humanum arte et ratione vivit. Arte et ratione... - so man lives on science! Science, equals the search for the truth about himself, about the world and the universe around him". ${ }^{2}$

${ }^{87}$ Fides et Ratio, nr. 40, 58, 74, 76.

${ }^{88}$ Cf. Jan Paweł II, Przekroczyć próg nadziei, pp. 41-46, 155-156; W. Dłubacz, Filozoficzne podstawy nadziei, p. 255.

${ }^{89}$ Fides et Ratio, nr. 86-87.

${ }^{90}$ Also in the context of preparation candidates to the priesthood and as well as in the general study of theology, where faith is not afraid of the intellect and gratia supponit naturam. Fides et Ratio, nr. 43; cf. Veritatis Splendor, nr. 4. Here the "study of philosophy comes up as a fundamental and crucial element..." Fides et Ratio, nr. 62, where consequently it is related to tradition (especially at St. Thomas). Fides et Ratio, nr. 85 and critical is to comprehend in the light of faith the modern theories (systems and methods). Fides et Ratio, nr. 51 it should lead to expose the truth, which is only one. Fides et Ratio, nr. 79, 106.

${ }^{91}$ Fides et Ratio, nr. 79, 106.

${ }^{92}$ Jan Paweł II, Nauka polska na wirażu dziejów. Przemówienie Jana Pawła II do rektorów polskich uczelni akademickich wygłoszone 4 stycznia 1996 r. w Rzymie, "Tygodnik Powszechny" 2 (1996), p. 10. 


\section{Bibliography}

Bartnik C., Personalizm teologiczny według Kardynała Karola Wojtyły, Zeszyty Naukowe KUL 1-3 (1979), pp. 51-60.

Boniecki A. (ed.), Kalendarium życia Karola Wojtyły, Kraków 2000.

Buttiglione R., Etyka w kryzysie, Lublin 1994.

Buttiglione R., Myśl Karola Wojtyły, Lublin 1996.

Centesimus Annus

Chudy W., Pedagogia godności. Elementy etyki pedagogicznej, Lublin 2009.

Chudy W., Rozwój filozofowania a "pułapka refleksji”. Filozofia refleksji i próby jej przezwyciężenia, Lublin 1995.

Chudy W., Wprowadzenie - na odsiecz prawdzie o osobie ludzkiej, in: R. Buttiglione, Myśl Karola Wojtyły, Lublin 1996.

Darowski R., Filozofia człowieka, Kraków 1995.

Drożdż A., Jan Paweł II nauczycielem moralności, “Currenda” 4 (1993), pp. 586-599.

Dyskusja nad dziełem Kard. Karola Wojtyly "Osoba i czyn”, "Analecta Cracoviensia” 5-6 (1973-1974), pp. 49-297.

Fides et Ratio

Filipiak M., Szostek A., Bibliografia prac naukowych kardynała Karola Wojtyły, Zeszyty Naukowe KUL 1-3 (1979), pp. 155-170.

Forycki R., Antropologia w ujęciu Kardynała Karola Wojtyły, "Analecta Cracoviensia" 5-6 (1973-1974), pp. 117-124.

Galarowicz J., Człowiek jest osobą. Podstawy antropologii filozoficznej Karola Wojtyły, Kęty 2000 (II ${ }^{\text {nd }}$ ed.).

Galarowicz J., Człowiek jest osobą. Podstawy antropologii filozoficznej Karola Wojtyły, Kraków 1994.

Galarowicz J., Ja - bliźni - wspólnota (Karola Wojtyły teoria uczestnictwa), "Studia Filozoficzne" 2-3 (1990), pp. 159-169.

Galarowicz J., Na ścieżkach prawdy. Wprowadzenie do filozofii, Kraków 1992.

Gałkowski J. W., Samostanowienie osoby w ujęciu kardynała Karola Wojtyły, "Zeszyty Naukowe KUL” 1-3 (1979), p. 73-79.

Gaudium et spes. Pastoral Constitution on the Church in the Modern World.

Gerjolj S., Moralno in religijsko učenje in poučevanje pred novimi izzivi, "Bogoslovni vestnik" 66 (2006) Nr 2, pp. 189-203.

Gogacz M., Hermeneutyka osoby i czynu (rec. ksiażki księdza kard. K. Wojtyły Osoba i czyn. Kraków 1969), "Analecta Cracoviensia” 5-6 (1973-1974), pp. 125-138.

Guitton J., Mój testament filozoficzny, Warszawa 1999.

Heller M., Liana Z., Mączka J., Skoczny W., Nauki przyrodnicze a teologia: Konflikt i wspótistnienie, Tarnów 2001. 
Jan Paweł II, Mężczyzna i niewiasta stworzył ich, Watykan 1986.

Jan Paweł II, Nauka polska na wirażu dziejów. Przemówienie Jana Pawła II do rektorów polskich uczelni akademickich wygłoszone 4 stycznia 1996 r. w Rzymie, "Tygodnik Powszechny" 2 (1996), p. 10.

Jan Paweł II, Przekroczyć próg nadziei, Lublin 1994.

Jaworski M., Koncepcja antropologii filozoficznej w ujęciu Kard. Karola Wojtyły, "Analecta Cracoviensia" 5-6 (1973-1974), pp. 91-106.

Kalinowski J., Metafizyka i fenomenologia osoby ludzkiej. Pytania wywołane przez "Osobe i czyn", "Analecta Cracoviensia" 5-6 (1973-1974), pp. 63-71.

Kamiński S., Jak filozofować o człowieku, “Analecta Cracoviensia” 5-6 (1973-1974), pp. 73-79.

Kłósak K., Teoria doświadczenia człowieka w ujęciu Kardynała Karola Wojtyły, “Analecta Cracoviensia” 5-6 (1973-1974), pp. 81-84.

Kowalczyk S., Człowiek w myśli współczesnej, Warszawa 1990.

Kowalczyk S., Tomistyczno-fenomenologiczny personalizm kard. Karola Wojtyły, "Ateneum Kapłańskie" 455-456 (1985), pp. 84-95.

Kowalczyk S., Z refleksji nad człowiekiem. Człowiek - społeczność - wartość, Lublin 1995.

Krąpiec M. A., Człowiek - suwerenny byt osobowy w ujęciu K. Wojtyły, "Zeszyty Naukowe KUL” 1-3 (1979), pp. 65-71.

Krąpiec M. A., Książka Kardynała Karola Wojtyły monografia osoby jako podmiotu moralności, "Analecta Cracoviensia" 5-6 (1973-1974), pp. 57-61.

Królikowski J., Jan Paweł II a powrót do chrześcijańskich korzeni Europy, "Currenda" 4 (1993), pp. 600-615.

Kuc L., Uczestnictwo w człowieczeństwie “innych"?, "Analecta Cracoviensia” 5-6 (1973-1974), pp. 183-190.

Kupczak J., W stronę wolności. Szkice o antropologii Karola Wojtyły, Kraków 1999.

Legowicz J. (ed.), Historia filozofii średniowiecznej, Warszawa 1979.

Odilon-Gbènoukpo S., Snježana M., Integral Education: TheologicalPedagogical Emphases in the Light of Church Teaching, "Bogoslovska Smotra" 91 (2021) Nr 1, pp. 51-72.

Osewska E., Personalizm jako fundament wychowania w szkole, in: Wychowanie a wyzwania ponowoczesności, ed. E. Osewska, Warszawa 2011, wyd. UKSW, pp. 81-90.

Osewska E., Simonič B., A Civilization of Love according to John Paul II, "The Person and the Challenges“ 9 (2019) nr 1, pp. 23-32, DOI: http://dx.doi.org/10.15633/pch.3359

Palacz R., Klasycy filozofii, Warszawa 1987.

Pawlak Z. (ed.), Katolicyzm A-Z, Poznań 1994.

Półtawski A., Człowiek jako istota realizująca się w czynie. Antropologia Karola Wojtyły a Henri Eya analiza świadomości, "Studia Philosopiae Christianae" 2 (1981), pp. 135-174.

Redemptor Hominis

Rodziński A., Tomizm a personalizm, Zeszyty Naukowe KUL 4 (1969), pp. 21-30. 
Scheler M., Resentyment a moralność, Warszawa 1997.

Skarga B. (ed.), Przewodnik po literaturze filozoficzne XX wieku, Vol. 3, Warszawa 1995.

Stala J., Der Mensch als Person: Die bestimmende Grundlage für Johannes Paul II. in seinem Bild von der Familie, "The Person and the Challenges" 2 (2012) nr 2, pp. 41-59.

Stępień A. B., Fenomenologia tomizująca w książce "Osoba i czyn”, "Analecta Cracoviensia” 5-6 (1973-1974), pp. 155-157.

Stępień A. B., Studia i szkice filozoficzne, Vol. 2, Lublin 2001.

Styczeń T., "Transcendencja - drugie imię osoby" czyli człowiek widziany z "niskości" doświadczenia samego siebie i z"wysokości krzyża”, “Znak” 401 (1988), pp. 3-30.

Styczeń T., Metoda antropologii filozoficznej w "Osobie i czynie”, "Analecta Cracoviensia" 5-6 (1973-1974), pp. 107-115.

Styczeń T., Zdybicka Z. (ed.), Czytając “Przekroczyć próg nadziei”, Lublin 1995.

Szewczyk W., Czy fenomenologia może się przydać psychologii współczesnej, “Znak” 271 (1977), pp. 35-45.

Szewczyk W., Jana Pawła II widzenie świata, “Currenda” 4 (1993), pp. 570-585.

Szewczyk W., Kim jest człowiek. Zarys antropologii filozoficznej, Tarnów 1994.

Tischner J., Metodologiczna strona dzieła "Osoba i czyn”, “Analecta Cracoviensia” 5-6 (1973-1974), pp. 85-89.

Veritatis Splendor.

Vincelette A., The Church Does Have a Philosophy of Her Own: Ruminations on Fides et Ratio and the First Principles of Catholic Philosophy, "Bogoslovni vestnik" 73 (2013) Nr 1, pp. 17-46.

W prawdzie ku wolności. W kręgu encykliki Veritatis Splendor, red. E. Janiak, Wrocław 1994.

Weigel G., Świadek nadziei. Biografia Papieża Jana Pawła II, Kraków 2000.

Wojtyła K., Ocena możliwości zbudowania etyki chrześcijańskiej przy założeniach systemu Maksa Schelera, Lublin 1959.

Wojtyła K., Osoba - podmiot i wspólnota, "Roczniki Filozoficzne” 2 (1976), pp. 5-39.

Wojtyła K., Osoba i czyn, Kraków 1969.

Wojtyła K., Problem doświadczenia w etyce, “Roczniki Filozoficzne” 2 (1969), pp. 5-24.

Wojtyła K., Słowo końcowe, “Analecta Cracoviensia” 5-6 (1973-1974), pp. 243-263.

Wojtyła K., The Acting Person, Boston 1979.

Wojtyła K., Wykłady lubelskie, Lublin 1986.

Wojtyła K., Zagadnienie wiary w dziełach św. Jana od Krzyża, Kraków 1990.

Wojtyła K., Znak, któremu sprzeciwiać się będa, Poznań-Warszawa 1976.

Zdybicka Z., Praktyczne aspekty dociekań przedstawionych $w$ dziele "Osoba i czyn", "Analecta Cracoviensia" 5-6 (1973-1974), pp. 201-205.

Życiński J., Stużąc człowiekowi i prawdzie. Piętnastolecie Pontyfikatu Jana Pawła II, "Currenda" 4 (1993), pp. 557-563. 